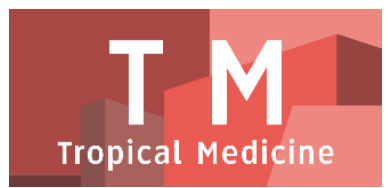

PAPER - OPEN ACCESS

Faktor-Faktor Penghambat Pelaksanaan Program KB Dalam Penggunaan Alat Kontrasepsi Oleh Pasangan Usia Subur Di Kecamatan Sarudik Kabupaten Tapanuli-Tengah

Author : Ismail Affandy Siregar

DOI $\quad: 10.32734 / \mathrm{tm} . v 1 i 1.47$

Paper Page : $99-106$

Volume 1 Issue 1 - 2018 TALENTA Conference Series: Tropical Medicine (TM)

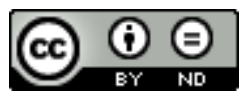

This work is licensed under a Creative Commons Attribution-NoDerivatives 4.0 International License.

Published under licence by TALENTA Publisher, Universitas Sumatera Utara
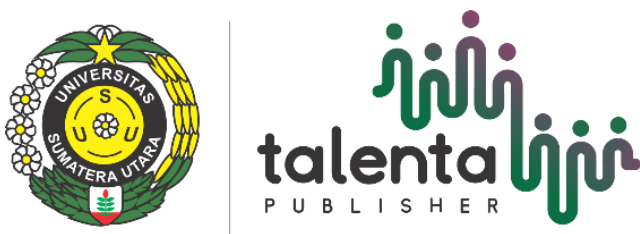


\title{
Faktor-Faktor Penghambat Pelaksanaan Program KB Dalam Penggunaan Alat Kontrasepsi Oleh Pasangan Usia Subur Di Kecamatan Sarudik Kabupaten Tapanuli-Tengah
}

\author{
Ismail Affandy Siregar ${ }^{a, *}$, Cholina Trisa Siregar ${ }^{\mathrm{a}}$ \\ ${ }^{a}$ Fakultas Keperawatan, Universitas Sumatera Utara, Medan 20155
}

\author{
ismailaffandy@gmail.com
}

\begin{abstract}
Abstrak
Keluarga Berencana adalah suatu program yang dimaksudkan untuk membantu para pasangan dalam mencapai tujuan reproduksi, mencegah kehamilan yang tidak diinginkan dan mengurangi insiden kehamilan berisiko tinggi, kesakitan dan kematian. Program keluarga berencana selalu dikaitkan dengan alat kontrasepsi karena untuk mengupayakan suatu program KB maka alat kontrasepsi merupakan kendaraan yang digunakan dalam menyukseskan program tersebut. Keberhasilan Program Keluarga Berencana di kecamatan Sarudik belum maksimal salah satunya ditandai dengan rata - rata kelahiran 4 per wanita usia subur. Tujuan penelitian ini adalah untuk mengidentifikasi faktor -faktor penghambat pelaksanaan program KB dalam penggunaan alat kontrasepsi. Penelitian ini merupakan penelitian kuantitatif. Populasinya adalah Pasangan Usia Subur yang tidak menggunakan alat kontrasepsi yaitu sebanyak 1404 dan sampelnya sebanyak 150 responden. Hasil penelitian diperoleh mayoritas responden yaitu 89 responden atau $(59,3 \%)$ termasuk pada kategori pengetahuan kurang baik, pada faktor sikap juga terdapat 95 responden atau $(63,3 \%)$ termasuk pada kategori kurang baik, faktor dukungan suami terdapat 112 responden $(74,7 \%)$ termasuk pada kategori tidak mendukung, faktor pendapatan keluarga terdapat 97 responden atau $(64,7 \%)$ termasuk pada kategori tidak mendukung program $\mathrm{KB}$, faktor karena efek samping juga tinggi yaitu terdapat 116 responden atau $(77,3 \%)$ termasuk pada kategori tidak mendukung program KB. Penelitian ini menyarankan kepada instansi terkait untuk meningkatkan sosialisasi program KB dan meningkatkan pelayanan kontrasepsi serta pendekatan kepada tokoh masyarakat, tokoh agama untuk mempermudah sosialisasi pada masyarakat.
\end{abstract}

Kata Kunci: factor-faktor penghambat; keluarga berencana; alat kontrasepsi; psangan usia subur

\section{Pendahuluan}

Hasil sensus penduduk pada tahun 2010 mencatat, indonesia berada pada peringkat ke-4 sebagai negara dengan jumlah penduduk terbesar yakni 237.556 .363 orang [7]. Indonesia sebagai negara dengan jumlah penduduk terbesar ke -4 saat ini memiliki berbagai masalah yang dapat menghambat pembangunan nasional, khususnya pada bidang kesehatan.

Menurut WHO dalam Maryunani (2009) data BBLR dirincikan sebanyak 17\% dari 25 juta persalinan pertahun didunia dan hampir semua terjadi dinegara berkembang. Angka kejadian BBLR di Indonesia adalah (10,5\%) masih di atas angka rata-rata Thailand $(9,6 \%)$ dan Vietnam (5,2\%). BBLR dan prematur merupakan penyebab kematian neonatal yang tinggi di Indonesia. Angka kematian bayi merupakan indikator menggambarkan kondisi kesehatan 
masyarakat, hal ini disebabkan bayi sangat peka terhadap kondisi lingkungan dimana ia hidup serta kondisi sosial, ekonomi dan budaya orang tua bayi bersangkutan. Angka kematian bayi di Indonesia pada tahun 2012 adalah 32 per 1.000 kelahiran hidup hal ini masih tinggi jika dibandingkan dengan Negara ASEAN lainnya. Angka kematian ibu karena melahirkan di Indonesia merupakan yang tertinggi juga di antara negara ASEAN yaitu 359 per 100 ribu kelahiran dari rata-rata kelahiran sekitar 3.5 juta setiap tahun (SDKI, 2012).

Program Keluarga Berencana (KB) merupakan upaya pemerintah dalam pengendalian penduduk terutama dalam pertumbuhan penduduk, hal ini dapat dilihat dalam pengaturan kelahiran. Pengendalian jumlah penduduk melalui Program Keluarga Berencana saat ini belum maksimal, hal ini ditandai jumlah penduduk di indonesia terus meningkat, laju pertumbuhan penduduk indonesia mencapai 1,49. Angka kelahiran di Indonesia pada tahun 2015 cukup besar yaitu mencapai 4.880 .951 bayi yang dilahirkan atau setara dengan jumlah penduduk Singapura (BPS 2015). Di Sumatera Utara angka kelahiran bayi mencapai 267.239 jumlah kelahiran menempatkan Sumatera Utara berada pada peringkat ke empat provinsi dengan populasi dan pertumbuhan penduduk tertinggi (Dinas Kesehatan Sumatera Utara, 2013), di kabupaten Tapanuli - Tengah angka kelahiran bayi mencapai 5.146 jumlah kelahiran, dan di kecamatan Sarudik angka kelahiran bayi yaitu 3,8 per wanita usia subur hal ini masih cukup tinggi [8].

Data dari (Laporan Perkembangan Program KKBPK Tahun 2015) mencatat jumlah PUS pada bulan Agustus 2015 di Indonesia mencapai 45.968.242 pasangan, sedangkan jumlah PUS bukan peserta KB yaitu 11.737.457 pasangan, di Sumatera Utara jumlah PUS mencapai 2.123.656 pasangan, sedangkan PUS bukan peserta KB yaitu 980.876 pasangan. Jumlah PUS di Tapanuli - Tengah mencapai 44.600 pasangan sedangkan PUS bukan peserta KB yaitu 22.697 pasangan, di Sarudik jumlah PUS mencapai 2.701 pasangan sedangkan PUS bukan peserta KB yaitu 1.404 pasangan.

\section{Metode Penelitian}

Penelitian ini menggunakan desain penelitian deskriptif untuk menggambarkan faktor-faktor yang menghambat PUS menggunakan alat kontrasepsi [11]. Populasi dalam penelitian ini adalah PUS yang bukan peserta KB di Kecamatan Sarudik, Kabupaten Tapanuli - Tengah yang berjumlah 1404 pasangan. Kecamatan Sarudik terdiri dari 5 Desa/kelurahan dan 28 Rusun / RW.

Sampel dalam penelitian ini adalah pasangan usia subur (PUS) yang bukan peserta KB di Kecamatan Sarudik Kabupaten Tapanuli - Tengah. Penentuan sampel dapat menggunakan patokan rasio 20:1 yang artinya untuk satu variabel seharusnya ada 20 sampel (Riyanto, 2012). Dengan menggunakan rumus $20 \mathrm{k}$ ( $\mathrm{k}=$ jumlah variabel), dalam penelitian ini jumlah variabel $=6$. Sehingga jumlah responden sebanyak $6 \times 25=150$. Alat pengumpulan data yang dipergunakan pada penelitian ini adalah kuesioner yang dimodifikasi oleh peneliti dan disusun secara literatur tertutup sehingga responden hanya memilih jawaban yang ada.

\section{Hasil Penelitian}

Tabel 1 didapatkan data responden dengan rentan usia 26 - 35 tahun (masa dewasa awal) berjumlah 75 responden atau (50\%) dan rentan usia 36 - 45 tahun (masa dewasa akhir) juga berjumlah 75 responden atau (50\%), kemudian dari aspek tingkat pendidikan bahwa sebagian pendidikan terakhir responden adalah Sekolah Menengah Pertama (SMP) yaitu 72 orang (48\%), dan sebagian besar responden beragama islam dengan jumlah 115 orang atau $(76,7 \%)$ dari total sampel, serta dari data jumlah kelahiran diketahui sebagian besar responden melahirkan sebanyak 4 kali yaitu $87 \mathrm{ibu}(58 \%)$.

Tabel 1. Distribusi frekuensi karakteristik responden di Kecamatan Sarudik

\begin{tabular}{lcc}
\hline Karakteristik & Frekuensi & Persentase (\%) \\
\hline Umur: & & \\
$26-35$ tahun & 75 & 50 \\
$26-35$ tahun & 75 & 50
\end{tabular}


Pendidikan:

\begin{tabular}{lcc} 
SD & 24 & 16 \\
SMP & 72 & 48 \\
SMA & 51 & 34 \\
D-III & 1 & 0,7 \\
S-I & 2 & 1,3 \\
Agama: & & \\
Islam & 115 & 76,7 \\
Kristen & 35 & 23,3 \\
Varitas: & & \\
3 & 14 & 9,3 \\
4 & 87 & 58 \\
$>4$ & 49 & 32,7 \\
\hline
\end{tabular}

Berdasarkan tabel 2 di atas bahwa mayoritas responden berada dalam kategori pengetahuan kurang baik yaitu 89 responden $(59,3 \%)$ dan responden yang termasuk dalam kategori pengetahuan cukup yaitu 45 repsonden (30\%)serta hanya sebagian kecil responden berada dalam kategori baik yaitu sebanyak 16 responden $(10,7 \%)$.

Tabel 2 Distribusi frekuensi tingkat pengetahuan responden tentang Program Keluarga Berencana dalam penggunaan alat kontrasespi di Kecamatan Sarudik Kabupaten Tapanuli -Tengah

\begin{tabular}{lcc}
\hline Pengetahuan & Frekuensi & Persentase (\%) \\
\hline Kurang & 89 & 59,3 \\
Cukup & 45 & 30 \\
Baik & 16 & 10,7 \\
\hline
\end{tabular}

Frekuensi tertinggi pada distribusi frekuensi sikap responden dapat dilihat pada tabel 5.1.3 yaitu berjumlah 84 responden atau (56\%)pada kategori kurang baik, dan responden yang termasuk dalam kategori pengetahuan cukup yaitu 34 repsonden atau $(22,7 \%)$ sementara sikap responden yang masuk dalam kategori baik hanya 27 responden atau $(18 \%)$.

Tabel 3. Distribusi frekuensi sikap responden tentang Program Keluarga Berencana dalam penggunaan alat kontrasespi di Kecamatan Sarudik

\begin{tabular}{lcc}
\hline Sikap & Frekuensi & Persentase (\%) \\
\hline Kurang & 95 & 63,3 \\
Cukup & 34 & 22,7 \\
Baik & 21 & 14 \\
\hline
\end{tabular}

Tabel 4 menunjukkan hanya 38 atau $(25,3 \%)$ suami dari responden yang mendukung responden untuk mengikuti program KB dalam penggunaan alat kontrasepsi sementara terdapat 112 atau $(74,7 \%)$ suami yang tidak mendukung responden untuk mengikuti program KB yaitu dalam penggunaan alat kontrasepsi dan ini merupakan frekuensi tertinggi kedua setelah faktor efek samping.

Tabel 4. Distribusi frekuensi dukungan suami responden terhadap Program Keluarga Berencana dalam penggunaan alat kontrasespi di Kecamatan Sarudik

\begin{tabular}{lcc}
\hline Dukungan Suami & Frekuensi & Persentase (\%) \\
\hline Mendukung & 38 & 25,3 \\
Tidak Mendukung & 112 & 74,7 \\
\hline
\end{tabular}


Dari hasil penelitian terdapat 98 responden atau (65,3\%) dukungan sosial budaya di kecamatan Sarudik termasuk dalam kategori mendukung sementara dukungan sosial budaya di kecamatan Sarudik yang termasuk pada kategori tidak mendukung program Keluarga Berencana dalam penggunaan alat kontrasepsi terdapat 52 responden atau $(34,7 \%)$ responden.

Tabel 5. Distribusi frekuensi dukungan sosial budaya responden terhadap Program Keluarga Berencana dalam penggunaan alat kontrasespi di Kecamatan Sarudik

\begin{tabular}{lcc}
\hline Sosial Budaya & Frekuensi & Persentase (\%) \\
\hline Mendukung & 98 & 65,3 \\
Tidak Mendukung & 52 & 34,7 \\
\hline
\end{tabular}

Pada Tabel 6 terdapat 97 responden atau (64,7\%) termasuk dalam kategori tidak mendukung Program Keluarga Berencana dalam penggunaan alat kontrasepsi diteliti dari faktor pendapatan keluarga, hanya sebagian kecil responden dengan pendapatan keluarga yang termasuk kategori mendukung program Keluarga Berencana yaitu 53 responden atau $(35,3 \%)$ tentunya pelayanan gratis dalam penggunaan alat kontrasepsi perlu ditingkatkan lagi.

Tabel 6. Distribusi frekuensi pendapatan keluarga responden terhadap Program Keluarga Berencana dalam penggunaan alat kontrasespi di Kecamatan Sarudik.

\begin{tabular}{lcc}
\hline Pendapatan Keluarga & Frekuensi & Persentase (\%) \\
\hline Mendukung & 53 & 35,3 \\
Tidak Mendukung & 97 & 64,7 \\
\hline
\end{tabular}

Berdasarkan hasil penelitian dari jawaban responden terdapat 116 atau $(77,3 \%)$ responden termasuk dalam kategori tidak mendukung dikarenakan efek samping alat kontrasepsi dan hanya terdapat 34 atau (22,7\%) responden yang termasuk dalam kategori mendukung. Frekuensi responden yang termasuk dalam kategori efek samping merupakan yang tertinggi dari semua faktor yang diteliti.

Tabel 7. Distribusi frekuensi efek samping yang diketahui responden tentang Program Keluarga Berencana dalam penggunaan alat kontrasespi di Kecamatan Sarudik.

\begin{tabular}{lcc}
\hline Efek Samping & Frekuensi & Persentase (\%) \\
\hline Mendukung & 34 & 22,7 \\
Tidak Mendukung & 116 & 77,3 \\
\hline
\end{tabular}

\section{Pembahasan}

\subsection{Pengetahuan}

Kusumaningrum (2009) berpendapat bahwapengetahuan dapat mempengaruhi seseorang untuk menggunakan alat kontrasepsi. Pengetahuan yang baik tentang KB akan menjadikan sikap yang positif, sehingga kepatuhan dalam melaksanakan program KB akan meningkat dan sebaliknya bila pengetahuan kurang maka kepatuhan menjalani program KB berkurang [13].

Hasil penelitian ini diperoleh data bahwa tingkat pengetahuan 89 responden (59,3\%) tentang Keluarga Berencana dan alat kontrasepsi di kecamatan Sarudik kabupaten Tapanuli Tengah berada dalam kategori pengetahuan yang kurang baik. Yuliasri (2010) mengatakan bahwasalah satu penyebab tingginya angka kelahiran diakibatkan oleh tingkat pengetahuan masyarakat yang kurang baik tentang Keluarga Berencana khususnya tentang penggunaan alat kontrasepsi sehingga hal tersebut menjadi hambatan dalam menekan laju angka kelahiran.

Pengetahuan yang rendah tentang Keluarga Berencana dan alat kontrasepsi di kecamatan Sarudik disebabkan oleh rendahnyakesadaran masyarakat untuk ikut dalam program Keluarga Berencana sehingga sosialisasi yang 
dilakukan oleh instansi terkait kurang mendapat perhatian dari masyarakat, akses ke beberapa desa atau dusun yang sulit sehingga menghambat dalam hal sosialisasi dan pelayanan KB metode kontrasepsi, mayoritas masyarakat memiliki latar belakang pendidikan terakhir adalah SMP/Sederajat, terbatasnya materi program KB dan KR dalam kelompok kegiatan serta kualitas kader/tenaga kelompok kegiatan yang masih terbatas [8]. Peningkatan sosialisasi tentang Keluarga Berencana khususnya tentang alat kontrasepsi kepada Pasangan Usia Subur perlu dilakukanagarlebih banyak Pasangan Usia Subur ikut dalam penggunaan alat kontrasepsi.Yuliasri (2010) berpendapat bahwa peningkatan pengetahuan Pasangan Usia Subur dapat dilakukan dengan cara membuat sosialisasi menjadi lebih menarik dan berkualitas sehingga orang akan mudah untuk memahami pesan yang disampaikan. Ibu yang memperoleh informasi tentang keluarga berencana yang berkualitas akan mempunyai pemahaman yang benar tentang alat kontrasepsi yang tepat digunakan.Peningkatan sosialisasi tentang Keluarga Berencana dapat dilakukan melalui program BkkbN saat ini yaitu PIKRR (Pusat Informasi dan Konsultasi Kesehatan Reproduksi Remaja). Program terbaru dari BkkbN dalam upaya peningkatan sosialisasi Program KB diantara lain adalah: Pemilihan Duta Mahasiswa GenRe, GenRe Goes To School, GenRe Goes To Campus, Lomba Poster, dan Komedi GenRe. Program terbaru ini lebih menfokuskan pada remaja agar siap untuk berumah tangga dan matang dalam usia pernikahan sehingga pengetahuan tentang Keluarga Berencana menjadi lebih baik.

\subsection{Sikap}

Sikap merupakan reaksi atau respon yang masih tertutup dari seseorang terhadap stimulus atau objek. Sikap tidak dapat dilihat secara langsung, tetapi hanya dapat ditafsirkan terlebih dahulu dari perilaku yang tertutup. Sikap secara nyata menunjukkan konotasi adanya kesesuaian reaksi terhadap stimulus tertentu yang dalam kehidupan sehari-hari merupakan reaksi emosional terhadap soal (Notoatmodjo, 2003).

Delima (2014) mengatakan terdapat hubungan antara sikap dengan keikutsertaan ibu dalam Keluarga Berencana. Harahap (2014) juga mengemukakan hasil yang sama bahwa sikap ibu sangat berpengaruh terhadap perilaku dengan keinginan ibu untuk menggunakan alat kontrasepsi IUD. Hasil penelitian yang dilakukan di kecamatan Sarudik kabupaten Tapanuli - Tengah disimpulkan bahwa sikap ibu Pasangan Usia Subur terhadap Keluarga Berencana sebagian besar masih kurang baik, hal ini didukung oleh data hasil penelitian bahwa terdapat 95 responden atau 63,3\% termasuk pada kategori sikap yang kurang baik.

Sikap masyarakat yang kurang baik terhadap program KB di kecamatan Sarudik dipengaruhi olehPUS yang ingin hamil masih tinggi, drop out yang masih tinggi, sikap pria sebagai kepala rumah tangga yang belum mengizinkan istrinya untuk berKB masih tinggi, ketakutan akan efek samping yang terjadi, kesadaran PUS pentingnya program KB masih rendah ditandai dengan sulitnya petugas lapangan keluarga berencana menggarap akseptor KB, pengetahuan masyarakat yang masih rendah tentang program $\mathrm{KB}$, latar belakang pendidikan sebagian besar SMP(BkkbN,2015). Azwar (2005) mengatakan untuk mengubah sikap masyarakat menjadi sikap yang positif dipengaruhi oleh beberapa faktor yaitu: pengalaman pribadi, pengaruh orang lain yang dianggap penting,pengaruh kebudayaan,media massa,lembaga pendidikan dan lembaga agama serta pengaruh faktor emosional maka sosialisasi tentang keluarga berencana dan alat kontrasepsi dapat dilakukan melalui pendekatan faktor -faktor tersebut.

\subsection{Sikap}

Rezkitunnisa (2010) mengatakan dukungan suami sangat dibutuhkan dalam pemilihan alat kontrasepsi. Suami yang mengerti pentingnya Keluarga Berencana cenderung mendukung istrinya untuk menggunakan alat kontrasepsi yang bertujuan untuk melindungi istrinya dari komplikasi karena sering hamil atau memiliki banyak anak. Mendukung istri untuk menggunakan alat kontrasepsi, suami sebagai kepala keluarga dapat dikatakan mampu untuk memenuhi kebutuhan anggota keluarga baik dari segi materi, pendidikan, dan perhatian kepada anak-anaknya.

Hasil penelitian yang dilakukan di kecamatan Sarudik kabupaten Tapanuli - Tengah terdapat 112 suami dari responden atau $(74,7 \%)$ yang tidak mendukung istrinya untuk ikut dalam program Keluarga Berencana, baik dari izin maupun dukungan materi lainnya, dan hanya 38 suami responden atau (25,3\%) yang memberikan dukungan kepada istrinya. Rendahnya dukungan suami di kecamatan sarudik disebabkan oleh keyakinan bahwa anak sudah ada rezekinya, memiliki banyak anak banyak rezeki, dan tradisi adat bahwa anak laki - laki yang akan meneruskan 
marga menyebabkan suami enggan memberikan dukungan kepada istri untuk ikut dalam program Keluarga Berencana hal ini didukung oleh data rata - rata jumlah varitas ibu dengan 4 kelahiran, serta pengetahuan suami tentang Keluarga Berencana yang kurang baik [8].

Suami mempunyai peranan sebagai kepala keluarga yang mempunyai hak untuk mendukung atau tidak mendukung apa yang dilakukan istri sehingga dukungan suami dalam penggunaan metode kontrasepsi sangat diperlukan [8].Sulistyawati (2013) mengatakan pendekatan tentang pemahaman Keluarga Berencana seharusnya tidak saja pada istri melainkan pada suami,sehingga suami ikut dalam program Keluarga Berencana atau memberikan dukungan kepada istri untuk ikut dalam program Keluarga Berencana. Penelitian yang dilakukan oleh Khoirunnisa (2014) disimpulkan bahwa keberhasilan kontrasepsi IUD dari program pemerintah di Puskesmas Tegalrejo tahun 2014 tidak terlepas dari dukungan suami.

\subsection{Sosial Budaya}

Demartoto (2010) menyatakan sosial budaya masyarakat sangat memegang peranan yang besar terhadap perilaku masyarakat,pernyataan tersebut didukung oleh penelitian yang dilakukan oleh rizkitama dan indarawati (2012) mengemukakan keberhasilan vasektomi di kecamatan Paguyangan Kabupaten Brebes meliputi: pengetahuan, sikap, termasuk sosial budaya masyarakat yang baik dengan (86\%) dukungan sosial budaya dari masyarakat di kecamatan Paguyangan Kabupaten Brebes.

Faktor sosial budaya Dikecamatan Sarudik kabupaten Tapanuli - Tengah Faktor setelah dilakukan penelitian disimpulkan sosial budaya masyarakat kecamatan sarudik mendukung program Keluarga Berencana dalam penggunaan alat kontrasepsi yaitu dari 150 responden yang diteliti terdapat sebanyak 98 responden atau $(65,3 \%)$ termasuk dalam kategori mendukung program Keluarga Berencana.

Dukungan sosial budaya masyarakat Sarudik terhadap Keluarga Berencana dipengaruhi oleh keadaan sosial budaya masyarakat tapanuli - tengah yaitu semangat kebersamaan seluruh lapisan masyarakat dengan motto Sahata Saoloan.Sahata saoloan artinya menjunjung tinggi kesepakatan yang telah dibuat melalui pengaruh tokoh agama, tokoh adat, tokoh masyarakat. [7]. Sosialisasi Program Keluarga Berencana di Tapanuli - Tengah khususnya di kecamatan Sarudik melibatkan tokoh agama, tokoh adat, tokoh masyarakat yang dianggap memiliki pengaruh penting terhadap masyarakat. Tujuannya adalah agar masyarakat memperhatikan sosialisasi program Keluarga Berencana dan meyakinkan masyarakat bahwa program Keluarga Berencana tidak bertentangan dengan agama dan sosial budaya masyarakat [8]. Strategi sosialisasi dengan pendekatan pada tokoh agama, tokoh adat, tokoh masyarakat tertuang pada Rencana Kerja (RENJA) Badan Keluarga Berencana dan Kesejahteraan Keluarga Kabupaten Tapanuli - Tengah.

\subsection{Pendapatan Keluarga}

Hasil penelitian yang dilakukan tentang pendapatan keluarga di kecamatan Sarudik Kabupaten Tapanuli Tengah disimpulkan sebagian besar responden tidak menggunakan alat kontrasepsi dikarenakan pendapatan keluarga yang tidak memadai. Hasil penelitian ini diperoleh data bahwa 97 responden atau $(64,7 \%)$ tidak menggunakan alat kontrasepsi diteliti dari faktor pendapatan keluarganya, hanya 53 responden atau $(35,3 \%)$ yang mau menggunakan alat kontrasepsi

Pendapatan keluarga yang mayoritas tidak mendukung program KB dipengaruhi oleh beberapa faktor yaitu: latar belakang pendidikan yang rendah, jumlah varitas yang masih tinggi, kebutuhan dasar tidak terpenuhi [8]. Keraf (2001) menyatakan bahwa pendapatan berhubungan langsung dengan kebutuhan-kebutuhan keluarga, penghasilan yang tinggi dan teratur membawa dampak positif bagi keluarga karena keseluruhan kebutuhan sandang, pangan, papan dan transportasi serta kesehatan dapat terpenuhi. Keluarga yang pendapatannya rendah akan mengakibatkan keluarga mengalami kerawanan dalam pemenuhan kebutuhan hidup salah satunya adalah pemeliharaan kesehatan.

Penelitian Adhyani (2011) mengemukakan bahwa ada hubungan antara status ekonomi dengan pemilihan kontrasepsi, hal ini disebabkan karena masyarakat beranggapan bahwa didalam pemilihan alat kontrasepsi harus dilihat dari kapasitas kemampuan ekonomi untuk membeli kontrasepsi.Upaya yang bisa dilakukan untuk menekan laju kelahiran adalah dengan menggalakkan pelayanan gratis metode kontrasepsi bagi masyarakat di kecamatan 
Sarudik kabupaten Tapanuli - tengah tentunya dengan meningkatkan segala aspek yang mendukung program Keluarga Berencana [8]. Pada saat ini Pemerintah menyediakan secara gratis tiga jenis alokon di seluruh wilayah Indonesia, yaitu kondom, Alat Kontrasepsi Dalam Rahim (AKDR), dan susuk KB. Terdapat 7 provinsi yang menyediakan alokon lainnya juga secara gratis, yaitu Aceh, Nusa Tenggara Barat, Nusa Tenggara Timur, Maluku, Maluku Utara, Papua, dan Papua Barat. Di provinsi lain, selain kondom, AKDR, dan susuk KB, jenis alokon lainnya hanya tersedia secara gratis bagi masyarakat miskin (Keluarga Pra Sejahtera dan Keluarga Sejahtera 1),dengan demikian memang ada sebagian masyarakat yang harus membayar sendiri penggunaan alokon yang dibutuhkannya [17].

\subsection{Efek Samping}

Regland (2014) mengatakan bahwa ada hubungan antara efek samping dengan pemilihan alat kontrasepsi. Reaksi efek samping yang sering terjadi sebagai akibat penggunaan alat kontrasepsi yaitu: amenorhoe, perubahan berat badan, pusing dan sakit kepala (Sulistyawati, 2013).

Penelitian yang dilakukan di kecamatan Sarudik kabupaten Tapanuli - Tengah terdapat 116 responden atau 77,3\% termasuk pada kategori tidak mendukung Program KB dalam menggunakan alat kontrasepsi dikarenakan efek samping dari penggunaan alat kontrasepsi yang diketahui oleh responden.Penelitian yang dilakukan oleh Andria (2010) di desa Tanjung Anom menyatakan bahwa dari 25 orang yang tidak menggunakan alat kontrasepsi ternyata ada 20 orang $(80 \%)$ yang menyatakan bahwa ada efek samping sebagai akibat berKB sehingga responden tidak menggunakan alat kontarsepsi.Tingginya frekuensi tidak mendukung pada faktor efek samping disebabkan oleh ketersediaan alat kontrasepsi tidak sesuai dengan yang dibutuhkan oleh pasangan usia subur sehingga menimbulkan efek samping dari alat kontrasepsi tersebut, pasangan usia subur tidak melakukan konseling terkait dengan alat kontrasepsi yang akan digunakan sehingga alat kontrasepsi tidak sesuai dengan yang dibutuhkan, kurangnya petugas lapangan keluarga berencana sehingga konseling mengenai pemilihan alat kontrasepsi yang tepat menjadi terbatas, adanya komplikasi yang terjadi akibat pemasangan alat kontrasepsi khususnya MKJP sehingga menyebakan persepsi negatif terhadap alat kontrasepsi [8].

Efek samping akibat penggunaan alat kontrasepsi menandakan belum adanya alat kontrasepsi yang sempurna untuk itu tiga hal yang sangat penting diketahui oleh calon akseptor KB untuk meminimalkan efek samping yang bisa terjadi yakni: efektivitas, keamanan dan efek samping [15]. Strategi yang telah ditetapkan sesuai RENSTRA 2015-2016 diantaranya: penguatan komitmen para pemangku kepentingan baik pemerintah dan non pemerintah dalam pelayanan KB, peningkatan ketersediaan, keterjangkauan dan kualitas pelayanan KB termasuk pelayanan KIE dan Konseling, peningkatan jumlah permintaan pelayanan KB melalui perubahan nilai tentang jumlah anak ideal dalam keluarga.Strategi ini diharapkan mampu memperbaiki persepsi termasuk persepsi tentang efek samping dalam program Keluarga Berencana dalam penggunaan alat kontrasepsi.

\section{Kesimpulan}

Faktor pengetahuan dan sikap masyarakat di kecamatan Sarudik setelah dilakukan penelitian berada pada kategori kurang baik dan faktor dukungan suami, pendapatan keluarga serta efek samping termasuk pada kategori tidak mendukung program Keluarga Berencana. Faktor -faktor penghambat Pelaksanaan Program Keluarga Berencana dalam Penggunaan Alat Kontrasepsi disebabkan oleh: rendahnya kesadaran masyarakat untuk berpartisipasi pada program KB, akses ke dusun dan ke pelayanan kesehatan yang sulit, latar belakang pendidikan yang rendah, terbatasnya sarana dan prasarana pelaksanaan Program KB, adat istiadat yang menuntut adanya anak laki - laki sebagai penerus marga, TFR (Total Fertilized Rate) 3,8 sehingga kebutuhan dasar semakin tinggi dan pemeliharaan kesehatan menjadi terabaikan. 


\section{Daftar Pustaka}

[1] Adhyani, Rahma. (2011). Faktor- Faktor yang Berhubungan dengan Pemilihan Kontrasepsi non IUD pada akseptor KB wanita usia 20-39 tahun. Semarang

[2] Ahmadi, (2006). Penelitian Manfaat Ekonomi dan Pengelolaan Terhadap Perempuan Siklus PDCA Pelayanan Pemeriksaan Kehamilan. TIM. Jakarta

[3] Andria. (2010). Faktor-Faktor Yang Mempengaruhi Pasangan Usia Subur (PUS) Tidak Menggunakan Alat kontrasepsi. Dusun II Desa Tanjung Anom Kecamatan Pancur Batu Kabupaten Deli Serdang

[4] Anwar, M. Baziad, A. Prabowo, P. (2011). Ilmu Kandungan. Jakarta: PT Bina Pustaka Sarwono Prawirihardjo.

[5] Azwar, 2002. Sikap Manusia dan Pengukurannya. Jakarta: Rineka Cipta. 2005. Pengantar Administrasi Kesehatan. Jakarta: Binapura Aksara

[6] Burns, August. (2008). Pemberdayaan Wanita Dalam Bidang Kesehatan. Yogyakarta: Yayasan Essenta Medika.

[7] Badan Pusat Statistik. (2010). Kependudukan. Diakses pada 20 Desember 2015, dari http://www.bps.go.id/linkTabelStatis/view/id/1267 .(2010). SDKI. Diakses pada 20 Desember 2015, darihttp://microdata.bps.go.id/mikrodata/index.php/catalog/SDKI. (2012). Tapanuli Tengah dalam Angka. Diakses pada 18 April 2016. https://publikasibpstapanulitengahkab.files.wordpress.com

[8] BkkbN. (2008). Jaminan Mutu Pelayanan KB. Diakses pada tanggal 20 Desember 2015, www.bkkbn.go.id

[9] Delima, ayu alifia. (2014). Gambaran Pengetahuan dan Sikap Ibu Usia Subur terhadap Alat Kontrasepsi di Puskesmas Tamalanrea. Makassar: Universitas Hasanuddin

[10] Demartoto, agyo. (2008). Sistem sosial budaya Indonesia.Semarang: Unversitas Negeri Semarang

[11] Dharma, K Kelana.(2011). Metodologi Penelitian Keperawatan. Jakarta: Trans Info Media

[12] Friedmen.(1998). Keperawatan Keluarga. EGC. Jakarta

[13] Hakim, Rahman A. (2013). Faktor-faktor yang mempengaruhi Pasangan Usia Subur dalam Program KB. kecamatan Kauman kabupaten Ponorogo.

[14] Harahap, Albainah.(2014). Analisis Faktor - Faktor yang Mempengaruhi Rendahnya Pemakaian Alat Kontrasepsi oleh Ibu Pasangan Usia Subur. Desa Sabungan Kecamatan sungai Kanan Kabupaten Labuhan Batu Selatan

[15] Hartanto, Hanafi. (2004). Keluarga Berencana dan Kontrasepsi. Jakarta: Pustaka Sinar Harapan

[16] Hidayat, AAA. (2010). Metologi Pendidikan Kebidanan dan Tehnik Analisis Data. Jakarta: Salemba Medika.

[17] Kemenkes RI. (2013). Buletin Jendela Data dan informasi Kesehatan volume 2 Semester II.

[18] Keraf. (2001). Ilmu Pengetahuan. Jakarta : Kanisius

[19] Khoirunnisa, Luthfia (2014). Hubungan Dukunga Suami dengan Pemilihan Kontrasepsi IUD pada Akseptor Kontrasepsi IUD di Puskesmas Tegalrejo. Yogyakarta: Stikes Aisyiyah

[20] Kusmiran, E. (2014). Kesehatan reproduksi Remaja dan Wanita. Jakarta: Salemba Medika

[21] Kusumaningrum R. (2009). Faktor faktor yang Mempengaruhi Pemilihan Jenis Kontrasepsi yang digunakan pada Pasangan Usia Subur. Semarang: Fakultas Kedokteran Universitas Diponegoro

[22] Manuaba, Ida Ayu DS. Manuaba, Ida Ayu CM.et al. (2006). Buku ajar Kesehatan Reproduksi untuk Mahasiswa Bidan. Jakarta: Kedokteran ECG 